\title{
From development authorities to democratic institutions: Studies in planning and management transition in the Karachi Metropolitan Region
}

Commonwealth Journal of Local Governance

Issue 7: November 2010

http://epress.lib.uts.edu.au/ojs/index.php/cjlg

\author{
Noman Ahmed \\ Department of Architecture and Planning \\ NED University of Engineering and Technology \\ Karachi, Pakistan
}

\section{Introduction}

Karachi is a relatively young metropolis. The city is about three centuries old, founded as a port by local Hindu merchants and traders. The British conquered the city in 1839, occupied the entire principality of Sindh in 1843 and designated Karachi as headquarters of the territory. The city experienced different phases of growth. When Pakistan came into being in 1947, a large number of refugees entered the city and the population jumped from 435,000 in 1947 to $1,050,000$ in 1951. Karachi has remained the primate city of Pakistan, with a high annual growth rate of 5-7 percent per annum (Ahmed 1998). Current estimates suggest that the city has about 17 million inhabitants.

Karachi houses 7 per cent of the total population and 23 per cent of the urban population of Pakistan. Its current rate of growth is estimated at around 5 per cent, of which 3 per cent is due to natural increase and 2 per cent to migration from the other parts of the country. Karachi provides 25 per cent of federal revenue and 15 per cent of Pakistan's gross domestic product (GDP). In addition, 50 per cent of the country's bank deposits and 72 per cent of all issued capital is contributed by the city (Hasan 2010; CDGK 2008). It houses the country's largest stock market and about 26 per cent of the total national industrial establishments. 


\section{Governance Framework}

Pakistan comprises four provinces, namely Sindh, Punjab, Khyber Pukhtunkhwa (formerly North West Frontier Province) and Balochistan. These are administratively divided into 110 districts which are further sub-divided into sub-districts or towns. Government is composed of three tiers: federal, provincial and local. Local government is controlled by the provinces, which have departments and ministries of local government that oversee the affairs of local bodies. The federal government has also instituted a Ministry of Local Government and Rural Development for overall coordination and monitoring of local government affairs in the country (Planning Commission 1998). Many other government departments, autonomous bodies and semigovernment organizations also extend support and assistance to local government institutions. For example, the government created the National Reconstruction Bureau (NRB) in 1999 with an aim to reconstruct local governments and the police force. It devised a new system which was enforced from 2001. This is discussed in more detail in following sections.

There is well-defined hierarchy for urban management in Pakistan. This is outlined in Figures 1-3 below.

Figure 1: Territorial Classification

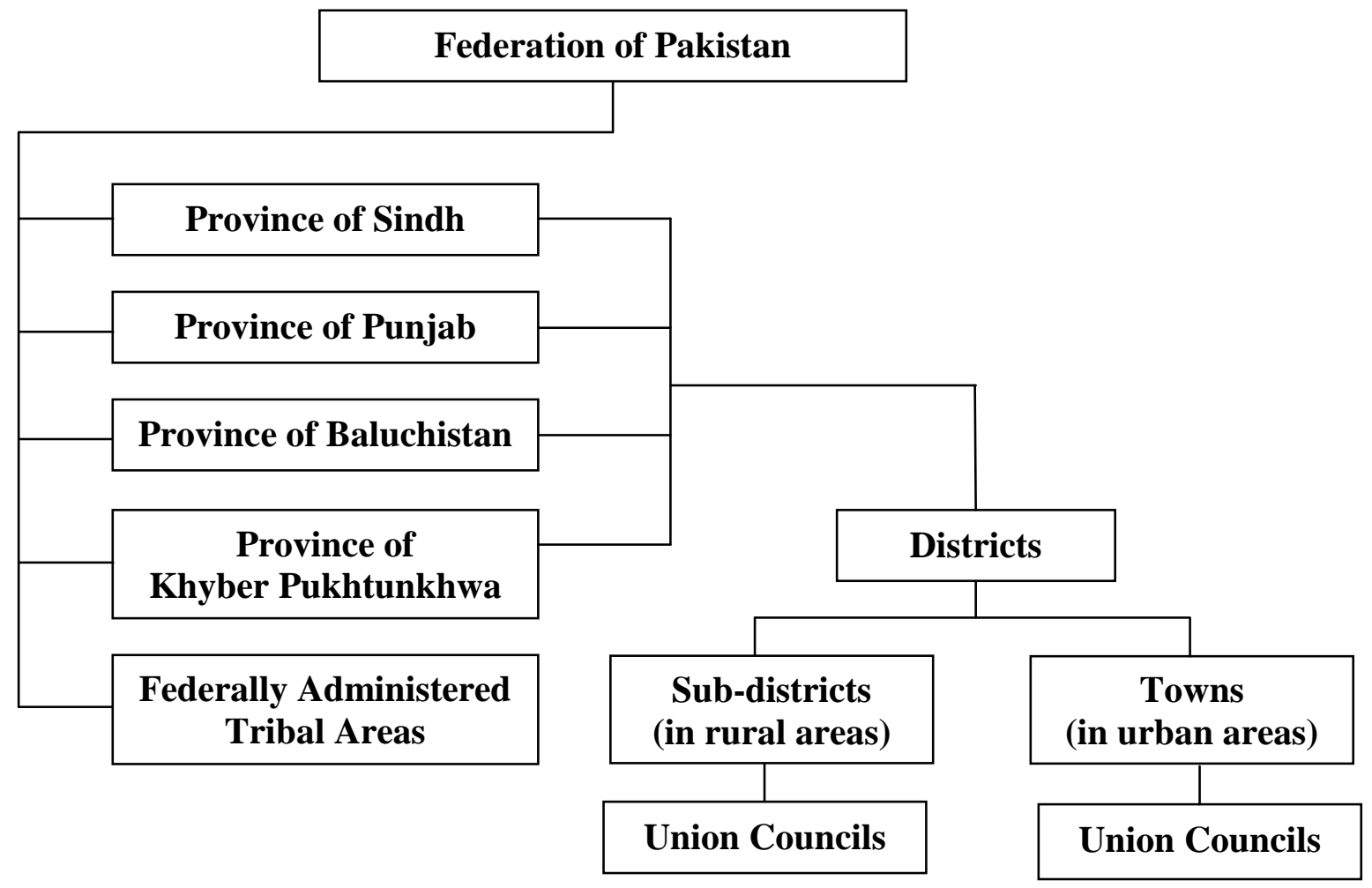


Figure 2: Government Hierarchy

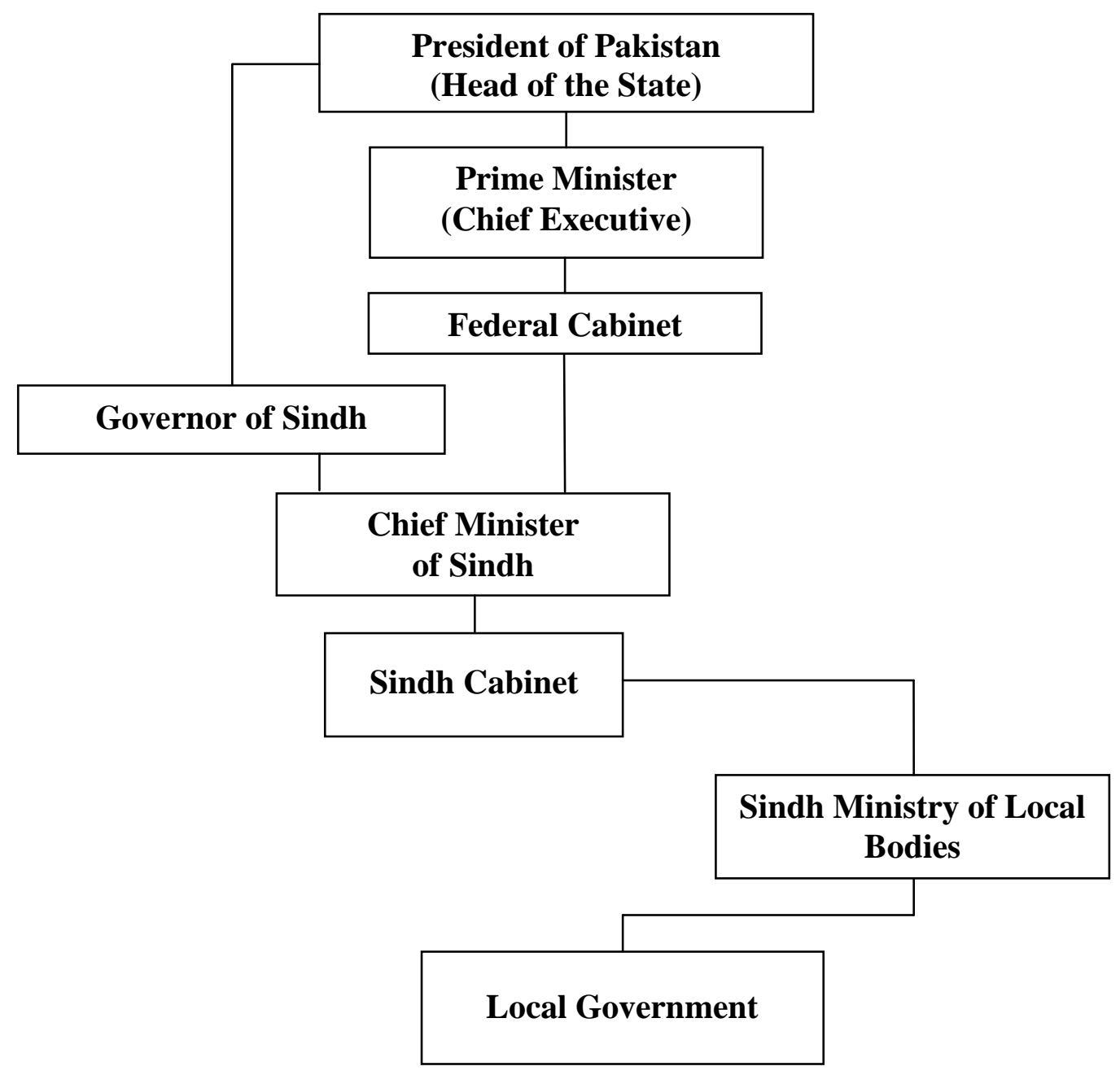


Figure 3: Administration of Karachi

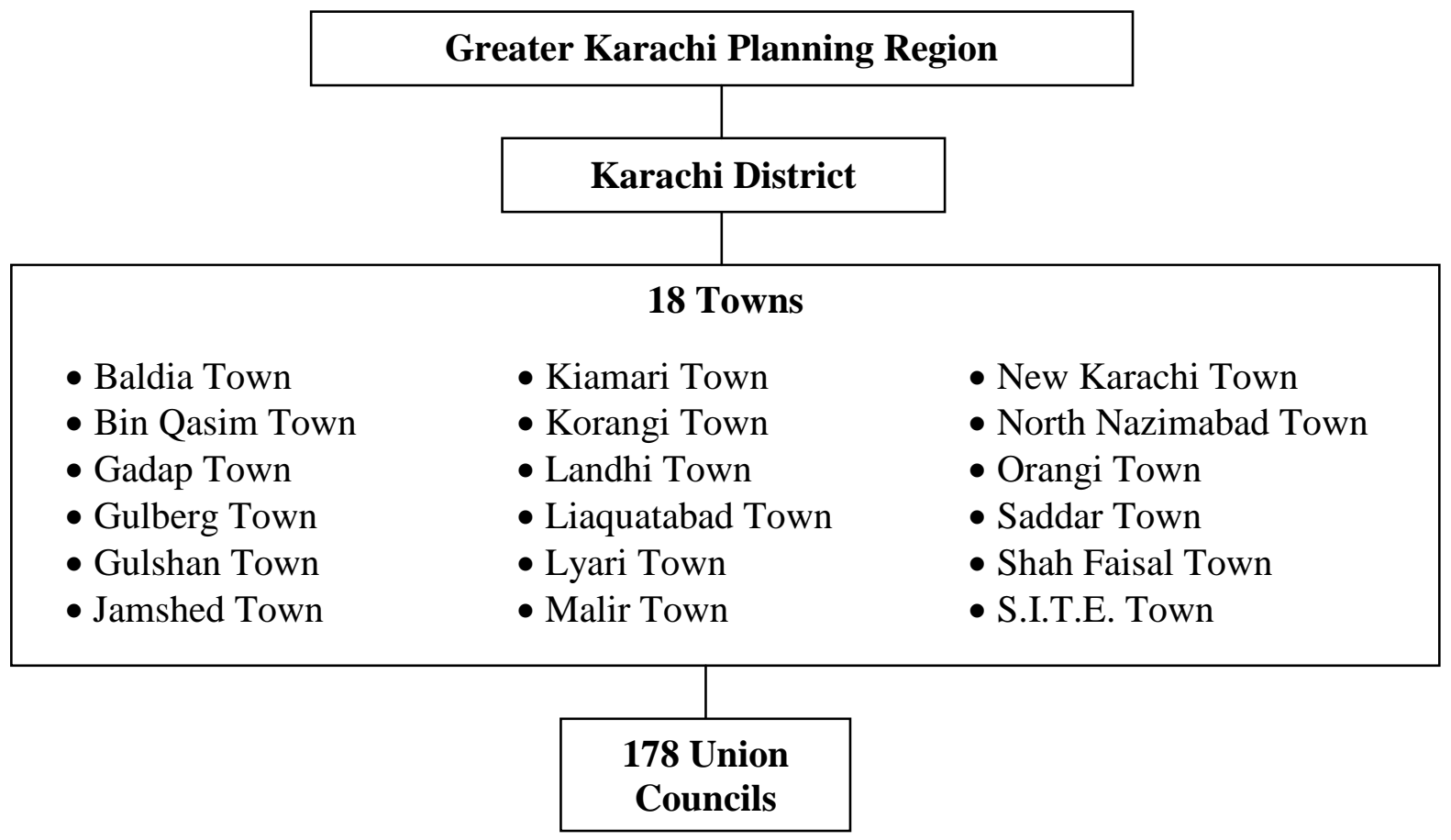

Source: CDGK website, www.cdgk.gov.pk (2010).

\section{Urban Management Structure of Karachi}

\section{Organizational development}

The organizational evolution and development of metropolitan administration in Karachi has passed through several phases in common with other similar cities in the Indo Pak Subcontinent. From a small scale municipality, the city has developed a complex urban management framework with a range of institutions of diverse nature, profile, functions, jurisdiction and approaches.

The Karachi Municipality was formed in 1852 by the British Government. It comprised appointed members, advisors and bureaucrats all approved by the provincial administration of Sindh. At this time the Sindh province was administered from Bombay, but in 1935, Sindh was completely separated from Bombay and the provincial headquarters were permanently settled in Karachi. In 1911, Karachi Municipality was partially restructured and representatives from the Karachi Chamber of Commerce and Industry, Karachi Port Trust and citizen committees/philanthropists also entered the 
council. It was upgraded as the Karachi Municipal Corporation (KMC). The arrangement was still non-representative in a democratic sense though led by a mayor elected from among the members.

In 1947, Pakistan came into existence and Karachi became its capital. Due to ample chances of employment, people emigrating from India flooded the city in large numbers. Several special directorates were set by the federal government in order to effectively deal with the refugee problem and urban rehabilitation. The Karachi Improvement Trust was formed in 1951 and upgraded to the Karachi Development Authority (KDA) in 1957. The KMC remained responsible for the municipal affairs of the old city quarters (Pithawalla 1960). In 1960 the capital was shifted to Islamabad, the newly planned city in northern Pakistan.

Also during this phase, the Basic Democracies Order of 1962 was issued by the President of Pakistan. It envisaged democratising the governmental organs from the lowest tier of the government. Under this Order, every 1250 people elected one representative to the new urban and rural councils (union councils, district councils and divisional councils in rural areas, and town committees, municipal committees and municipal corporations in urban areas). The KMC received its first batch of elected councilors in 1964, but the martial law of 1969 eradicated this representative structure (Ahmed 1998), and the period of 1971-79 saw KMC working as a core bureaucratic organ of government. The mayor was replaced by an appointed administrator who was solely responsible for all executive actions and initiatives.

The Sindh Local Government Ordinance of 1979 returned representative government and local elections were held that year. In Karachi, 167 councillors were elected from various constituencies of the city. Special representation was given to nominees of women, labour/major trade unions and minorities. These councillors elected the mayor and deputy mayor for a term of four years. The polls were held on non party basis, but later the councillors informally organized themselves into political groups within the council.

The second local elections took place in 1983 with the same structure. However, KMC was dismissed by the Sindh Chief Minister in 1987 over a conflict on sharing motor vehicle tax between the city and the provincial government. Also in 1987 Karachi was divided into four zones due to its large size and the administration of KMC accordingly 
split into four units, termed Zonal Municipal Committees. The number of councillors was increased to 245 in total. Elections to these new local bodies were held in 1988 on nonparty basis. The mayor was elected by the joint session of all the four committees. Municipal functions and delegation of power remained virtually unchanged (KMC 1990).

In 1993, the provincial government constituted two new authorities, namely the Malir and Lyari Development Authorities, to replace the Karachi Development Authority and take responsibility for planning, development, infrastructure provision, housing, landscape and horticulture and a number of other functions. The KMC and Zonal Municipal Committees remained responsible for 'routine' urban management tasks. In 1996, the city was further re-organized into five District Municipal Corporations (DMCs). The KMC remained perched on the top of DMCs with policy formulation, resource distribution and coordination functions (Ahmed 1998). All the municipal organs were headed by appointed bureaucrats.

Military rule was imposed on the country in 1999 and the military government introduced major local government reforms. Karachi was declared a City District to signify it as an urban area. Also a new Sindh Local Government Ordinance was promulgated in 2001 (SLGO 2001). The city was subdivided into 18 Towns and 178 Union Councils (UCs). At the same time, the KMC and development authorities were amalgamated to form a new City District Government Karachi.

Elections for the UCs were held in 2001, with the Nazim (mayor) of each UC subsequently becoming a voter to elect the Nazims their respective Towns and the City. Elections were again held in 2005. However, in 2010, the tenure of the elected regimes concluded, and they were replaced by appointed bureaucrats. Major constitutional changes are in the offing at present which will also have an impact on the status, structure and working of local governments.

\section{Local institutional structure}

As mentioned earlier, the Karachi Improvement Trust and later Karachi Development Authority (KDA) were established during the earlier post independence period. The KDA was composed of appointed managerial, technocratic and bureaucratic personnel. It had an appointed director general and a council comprised of the Mayor of Karachi, 
Managing Director of Karachi Water and Sewerage Board (KWSB) and two nominees from the provincial government, chaired by the Commissioner Karachi Division, an office which is now defunct. Autonomous in its conduct, it was accountable to the Ministry of Physical Planning and Housing, Government of Sindh. It performed the following functions:

- Master planning/planning coordination/environmental control/urban design/urban renewal

- Building codes and planning standards

- Provision/development of public Housing

- Providing technical assistance to the other bodies (when required)

- Land management and developmental control

- Maintenance of infrastructure (in coordination with KWSB)

- Mass-transit planning

- Development of low cost housing

Its sources of revenue were land sales and development charges.

Urban management functions rested with KMC till 2001. They included:

- Maintenance of urban areas, parks and recreation grounds

- Community services/amenities such as hospitals, dispensaries, maternity homes and schools

- Leasing of public property for development or other use

- Roads and street maintenance

- Coordination in planning and development activities

- Solid waste management

- Fire fighting services

- Squatter settlements

- Flood control

Its sources of revenue included Octroi (a tax imposed on the goods transported by road and rail until 1999 when it was abolished); property taxes levied on fully occupied and utilized property; road tolls; and fire services and conservancy taxes. In addition, occasional grants were obtained from the federal and provincial governments for specific projects. 
Until the KDA and other developmental authorities were merged with KMC, planning functions were managed by the Master Plan and Environmental Control Department (MPECD) of KDA. The MPECD collaborated with various national and international agencies for preparation of development plans. It produced two major planning studies and outputs, namely the Karachi Development Plan (1973-85) and the Karachi Development Plan (1986-2000). However, these plans were not notified, and as political and administrative support to the department began to dwindle, most of its staff and associated expert pool either sought employment in the private sector or left the country. When the next master planning exercise began in the early 2003, only a bare minimum of human resources remained. Thus this exercise was handed over to a private firm. This approach had many short comings as the said firm did not possess the overall competence and capability to undertake a large scale task of this nature.

As mentioned earlier, both KDA and KMC merged into the City District Government Karachi in 2001, according to a new local government dispensation. However the CDGK did not acquire control of building and development control, which were managed by the Karachi Building Control Authority (KBCA) which functioned under the provincial government of Sindh. Similarly, water and sanitation works remained under the Karachi Water and Sewerage Board (KWSB).

Delivery of services in Karachi is now undertaken by a complex web of multiple agencies with either singular or shared jurisdictions. This is shown in Table 1.

Table 1: Service Delivery Mechanisms in the Karachi Planning Region (KPR)

\begin{tabular}{|lccl|}
\hline Nature of Function & Jurisdiction & $\begin{array}{c}\text { Level of } \\
\text { Government }\end{array}$ & $\begin{array}{c}\text { Authority, Department or Unit } \\
\text { Performing Function }\end{array}$ \\
\hline General administration & $\begin{array}{c}\text { Karachi Planning } \\
\text { Region }\end{array}$ & $\begin{array}{c}\text { Local } \\
\text { GoS }\end{array}$ & $\begin{array}{l}\text { Administrator CDGK } \\
\text { Chief Secretary to GoS }\end{array}$ \\
\hline Administration of justice & Sindh & GoS & $\begin{array}{l}\text { Various civil and criminal courts headed } \\
\text { by the Sindh High Court }\end{array}$ \\
\hline Police & Sindh & GoS & Home Department, Police Department \\
\hline Traffic & Sindh & GoS & $\begin{array}{l}\text { Traffic Police and Transport \& } \\
\text { Communication Department CDGK }\end{array}$ \\
\hline Land development & KMA & $\begin{array}{c}\text { GoS } \\
\text { Local Authority } \\
\text { Private Sector }\end{array}$ & CDGK, DHA, other development agencies \\
\hline
\end{tabular}




\begin{tabular}{|c|c|c|c|}
\hline Housing & KPR & Same & Same \\
\hline Physical planning & KPR & Same & CDGK, other land owning bodies \\
\hline Bulk water supply & KPR & Same & KWSB \\
\hline Retail water distribution & KPR & Same & $\begin{array}{l}\text { CDGK, Cantonment Boards \& other } \\
\text { constituent units under the supervision of } \\
\text { KWSB }\end{array}$ \\
\hline \multicolumn{4}{|l|}{ Sewerage } \\
\hline Works & KPR & Same & KWSB \\
\hline $\begin{array}{l}\text { Treatment plants and } \\
\text { maintenance }\end{array}$ & KPR & Same & KWSB \\
\hline Fire-fighting & KPR & Same & $\begin{array}{l}\text { CDGK, Cantonment Boards, agencies of } \\
\text { the armed forces }\end{array}$ \\
\hline Environmental control & KPR & Same & CDGK, SEPA \\
\hline Environmental Sanitation & KPR & Same & $\begin{array}{l}\text { CDGK, Cantonment Boards, local } \\
\text { authorities }\end{array}$ \\
\hline Parks and playgrounds & KPR & Same & Same \\
\hline \multicolumn{4}{|l|}{ Education: } \\
\hline Primary & Sindh & Same & Education Dept., CDGK, Private Sector \\
\hline Secondary & Sindh & $\begin{array}{l}\text { Federal Govt. } \\
\text { GoS } \\
\text { Private Sector }\end{array}$ & Education Dept., Private Sector \\
\hline University & Sindh & GoS & $\begin{array}{l}\text { Higher Education Commission, Private } \\
\text { Sector, GoS }\end{array}$ \\
\hline Electricity & Sindh & Federal Govt. & KESC, WAPDA \\
\hline Gas & Sindh & Federal Govt. & Sui Gas Southern Company \\
\hline Telephone & Sindh & Federal Govt. & $\begin{array}{l}\text { Pakistan Telecommunication Co Ltd, } \\
\text { Private Sector }\end{array}$ \\
\hline \multicolumn{4}{|l|}{ Transport } \\
\hline Buses & KPR & Private Sector & Private Sector, CDGK \\
\hline Circular Railway & KPR & Federal Govt. & $\begin{array}{l}\text { Pakistan Railways, Karachi Urban } \\
\text { Transport Corporation }\end{array}$ \\
\hline $\begin{array}{l}\text { Taxis, mini-buses } \\
\text { rickshaws (para } \\
\text { transit) }\end{array}$ & KPR & Private Sector & Private Sector \\
\hline Port development & KPR & Federal Govt. & KPT, Port Qasim Authority \\
\hline
\end{tabular}




\begin{tabular}{|c|c|c|c|}
\hline Airport development & KPR & Federal Govt. & Civil Aviation Authority \\
\hline Industrial Estates & KPR & $\begin{array}{l}\text { GoS } \\
\text { Federal Govt. }\end{array}$ & $\begin{array}{l}\text { SITE, Export Processing Zone Authority, } \\
\text { Pakistan Steel }\end{array}$ \\
\hline Medical care & KPR & $\begin{array}{c}\text { Federal } \\
\text { GoS } \\
\text { Local Authority } \\
\text { Private Sector }\end{array}$ & $\begin{array}{l}\text { GoP, GoS, Dept. of Health, CDGK, other } \\
\text { Councils, Private Sector }\end{array}$ \\
\hline \multicolumn{4}{|l|}{ Collection of taxes: } \\
\hline $\begin{array}{l}\text { Property, betterment, } \\
\text { entertainment and } \\
\text { motor vehicles taxes }\end{array}$ & Sindh & GoS & Excise and Taxation Department \\
\hline $\begin{array}{l}\text { Custom, central } \\
\text { excise duties, sales } \\
\text { and income tax }\end{array}$ & Sindh & Federal Govt. & Federal Board of Revenue, GoP \\
\hline $\begin{array}{l}\text { Water, conservancy, } \\
\text { fire, and other } \\
\text { municipal taxes }\end{array}$ & KPR & Local Authorities & CDGK, Cantonment Boards \\
\hline
\end{tabular}

\begin{tabular}{|cl|}
\hline \multicolumn{2}{|l|}{ Notes: } \\
\hline GoP & Government of Pakistan \\
\hline SITE & Sindh Industrial and Trading Estates \\
\hline GoS & Government of Sindh \\
\hline KESC & Karachi Electric Supply Corporation \\
\hline KPR & Karachi Planning Region \\
\hline KPT & Karachi Port Trust \\
\hline KWSB & Karachi Water Sewerage Board \\
\hline LDA & Lyari Development Authority \\
\hline MDA & Malir Development Authority \\
\hline WAPDA & Water and Power Development Authority \\
\hline CDGK & City District Government Karachi \\
\hline DHA & Defence Housing Authority \\
\hline SEPA & Sindh Environmental Protection Agency \\
\hline
\end{tabular}

\section{Planning and Management in Transition}

\section{Trends in political leadership}

The early post-colonial leadership of Karachi was influential, honest and upright, possessed noble ideas, and contributed its best efforts to running the day-to-day affairs of the city as well as to resolve various crises. This phase lasted from 1947 to 1955 . After this period, the administration of the city was passed to the bureaucrats. The tradition of elected local government was only revived after a long gap in 1979. Partyless elections 
were held through which a house of councilors was elected. This leadership proved very fragile for a number of reasons. First, the Sindh Local Government Ordinance of 1979, which was the main law under which the municipalities of the province were constituted, provided only marginal independence to the municipalities. Thus it was difficult for the metropolitan leadership to emerge as a powerful voice of the citizens. Nevertheless, after 1987 the municipality was governed by councillors of a political group that represented the largest ethnic community residing in urban Sindh, and this group did produce viable leadership to run the affairs of the city. However, internal rifts, political deadlock with the upper tiers of the government, and acts of violence in the city disrupted the evolution of metropolitan leadership. In 1992, the elected local government was again abolished and was taken over by appointed officers and civil servants.

The re-vamped structure of local government in the form of CDGK has been dominated by various political groups, although elections have been held on a nominally non-party basis. In 2002, the Nazim (mayor) and other officers came largely from a religiopolitical party. Later, in 2005, the CDGK was dominated by the same ethno-political party that led the city's affairs during the late 1980s and early 1990s.

Metropolitan leadership reflects the various interest groups that exist in the city. Although there is no formal structure of governance which accommodates the input of these groups, the power structure informally functions in conformance with their preferences. The extent of influence of each interest group is difficult to quantify, but the following constitute important groups that influence the decision-making process.

- Builders and developers: These stakeholders have formed the Association of Builders and Developers (ABAD). Matters pertinent to land use, development of suburban areas, extension of infrastructure, and zoning by-laws and regulations are largely influenced by ABAD which enjoys close informal relations with the CDGK and the provincial administration.

- Informal land grabbers: They facilitate the occupation of state land through organized encroachments. They have been operating in the city for the past four decades and have converted almost one third of the urban land into informal settlements. They lobby for ownership rights and provision of basic services, and 
enjoy the patronage of political leaders as these settlements constitute the major voting banks for the political parties.

- Transporters: They are responsible for running the entire passenger and goods transport system of the city, and influence policies and projects related to the development of roads, alignment of passenger/goods routes, and fares.

- Religious pressure groups: Though their electoral influence is dwindling, they constitute a strong pressure group due to 'street power'. That is to say, the religious lobbyists possess within their folds a considerable number of staunch followers and activists who are used in street protests, demonstrations and agitation.

- Political parties: They have a vast following owing to Karachi's multi-ethnic and multicultural context. The dominant groups are the Urdu speaking immigrants from India who migrated to Pakistan to begin new lives and settled in Karachi as the city was only emerging urban centre in the country. They constituted an upwardly mobile and progressively minded community which wanted to break free from orthodox customs and traditions.

Apart from the Urdu speaking community, the Sindhis, Punjabis, Baluchis, and Pushtospeaking Pathans also form important groups in Karachi. With the growing insurgency in the northern parts of the country, a large number of internally displaced people have entered Karachi; most are Pushto speaking and their political power has increased considerably along with their numbers.

\section{Planning agencies and their roles}

During the post independence period, the planning process gradually evolved under the direct supervision and advice of federal and provincial governments. Although in theory the planning process at the metropolitan level is now the responsibility of the CDGK and other local development agencies, the key decisions are still largely instituted at the federal and provincial levels, and all large-scale program and projects are formulated and approved by the institutions of federal and provincial governments. In other words, the metropolitan organs have no autonomy in planning for the city and local government is limited largely to implementation of program and projects. In the absence of an effective 
local government, it is difficult to imagine that any urban planning process will function properly.

Land is undoubtedly the most important resource in the metropolitan planning process. In Karachi, there are about nineteen authorities that plan, develop, and float land in the market. Examples of such authorities include the Defence Housing Authority, Sindh Industrial and Trading Estate, Malir Development Authority (MDA), Lyari Development Authority (LDA), Karachi Port Trust (KPT), Port Qasim Authority, and the various Cooperative Societies. These agencies are independent in their respective actions and jurisdiction, although under the prevailing socio-political environment of the country, their decision-making is influenced by both upper-tier organs of government and the influential lobbies discussed earlier.

Neither the KDA nor the CDGK have possessed any legal or administrative control over these other development agencies of the city. Thus their capacity to execute plans has been grossly constrained. The most recent plan, the Karachi Strategic Development Plan 2020, managed by the Master Plan Group of Offices (MPGO) of the CDGK, suggested various investment options to the development agencies, but with little likelihood they will be implemented.

Thus planning exercises at the city level tend to be somewhat academic. Moreover, while the planning process improved in its methodology and execution, there are several shortcomings in content. The city of Karachi is grossly deficient in basic maps, property records, and physical and socio-economic inventories. As a result of the lack of adequate data, planning assumptions have been drawn from sample surveys. This has led to underor over-estimations. Each attempt at planning has focused on addressing this vital deficiency. The Karachi Strategic Development Plan 2020 is no exception, but since it was conceived as a finite consultancy project, the creation of a multipurpose data base could not be effectively pursued.

A wide gap has usually prevailed between the planning process and social, economic, administrative, and practical realities. This has become extremely visible during the last decade. The Karachi Strategic Development Plan 2020 has been criticized for this reason. The plan does not deal sufficiently or realistically with environment related issues nor take into consideration various social and political factors that have a direct bearing on 
the way the city is governed and development takes place. No viable institutional arrangements have been developed to oversee the implementation of the plan, although a clear analysis of the institutional issues involved was one of the outputs of the planning process.

Therefore the intended implementation process is not sustainable because: (a) there is no political support for the plan from provincial government; (b) there are no institutional arrangements for inter-agency transfer of information or data; (c) there is only lukewarm commitment to the planning process; (d) organizational culture within the CDGK is a major hindrance; and (e) the plan has not sought to develop links with the NGOs, informal sector, communities, and other development lobbyists whose support is essential to achieve its objectives.

Another problem with metropolitan planning is that each time the process has started afresh: the previous plan was consulted merely as a passing reference. Never until the most recent effort was an evaluation conducted to review the performance of past plans, and while the present plan did attempt an evaluation, it was confined only to basic records, not the review and analysis of developments on the ground.

It is also interesting to note that those groups who actually decide on the fate of the city were not invited to the policy or plan-making exercise. Transporters, shopkeepers, estate agents, brokers, dealers, religious and political groups, professionals, builders, and businessmen remained aloof throughout the process. Nor were local communities or the general public involved.

\section{Lessons Learned}

A viable political system that is capable of transforming populist aspirations into an agenda for development is a pre-requisite for any sustainable urban planning process. This process exists to some extent in Karachi, but only basic statutory provisions are contained in the Sindh Local Government Ordinance 2001 and planning lacks the robust legal framework needed to place this vital activity on a firm footing. In particular, better coordinated management of land is fundamental to an improved planning process, and planning and urban management institutions must have the ability to generate enough revenue to support their functions. 
Also an effective consultation process needs to be formed to develop a vision for the city and region. It must be understood that Karachi is more than a city; it is an expanded urban region. If we fail to give direction to its growth and sustenance, the city will become a melting pot of problems. Karachi is a mini-Pakistan as far as its composition is concerned. Therefore views from each discipline of learning and every section of society are vital to shape a consensus on the future of the metropolis. Furthermore, it is essential to initiate debates on crucial planning issues to raise popular awareness among the people. Although the newspapers and magazines are doing commendable work, it needs to be reinforced by the efforts from the electronic media which has a greater reach into the masses. CDGK could seek to create this institutional space.

Demonstration planning projects have a key role to play. A few of the town councils of Karachi should be selected for this purpose. Plans could be developed initially for those towns and after suitable review, evaluation and modification, the lessons learned may be extended to all the remaining jurisdictions in a systematic manner.

In order to develop a stronger professional base, universities and research institutions should be involved in the process. The universities should develop relevant specialized program whereby they become capable of providing professional support to this vital activity. According to their capacity and past performance, universities should be directly involved at least during the fact finding and evaluation phases of planning. Also, instead of creating competition, the approach of fostering collaboration between institutions should be promoted to gain benefit from the strengths of all concerned.

Planning is not a product; it is a continuous ongoing process and needs to be treated as such. 